\title{
Colletotrichum theobromicola causes defoliation, stem girdling and death of mini-cuttings of eucalyptus in Brazil
}

\author{
Ana L. Rodrigues, Danilo B. Pinho, Daniela O. Lisboa, Robson J. Nascimento, Olinto L. Pereira, Acelino \\ C. Alfenas \& Gleiber Q. Furtado \\ Departamento de Fitopatologia, Universidade Federal de Viçosa, Viçosa, MG, 36570-900, Brazil
}

Author for correspondence: Gleiber Q. Furtado, e-mail: gfurtado@ufv.br

\begin{abstract}
Eucalyptus plantations cover approximately 5.1 million hectares of Brazil, an area that will likely increase given the demand for natural products from planted forests. In recent years, anthracnose diseases have been frequently found on eucalyptus in Brazilian nurseries. In 2012, rooted mini-cuttings of clones of E. urophylla x E. grandis ("urograndis") exhibiting leaf spot and stem girdling symptoms were collected from nurseries in the Brazilian states of Pará and Minas Gerais, and cultures of Colletotrichum were obtained from the lesions. The isolates were initially identified to species of the $C$. gloeosporioides species complex, according to searches of the Q-bank Fungi database with the DNA sequences of their internal transcribed spacer (ITS) regions. Subsequent phylogenetic analysis of the $\beta$-tubulin (TUB2) and glyceraldehyde-3-phosphate dehydrogenase (GAPDH) regions, combined with morphological characterization, allowed us to conclude that the fungus belongs to C. theobromicola. Conidial suspension sprayed on "urograndis" clone plants induced similar symptoms as those found under natural conditions. Re-isolation of the fungus from symptomatic plants fulfilled the Koch's postulate. To our knowledge, this is the first report of $C$. theobromicola in Brazil.
\end{abstract}

Key words: Colletotrichum gloeosporioides, anthracnose, forest pathology, tropical fungi.

Approximately 5.1 million hectares of Brazil are planted with eucalyptus. Given the increasing demand for forest products and the pressure to reduce the use of wood and wood products sourced from native forests, this acreage is likely to expand in the near future (ABRAF, 2013). The expansion of planted areas represents a risk for the appearance of new diseases. Among the diseases affecting eucalyptus plantations, anthracnose is especially harmful in nurseries due to high susceptibility of some eucalyptus genotypes and the environment favorable for the disease (Alfenas et al., 2009).

In nurseries, clonal hedges and plantations, anthracnose diseases occur at phenological stages A and B (Ferreira \& Milani, 2002). The signs of the disease include the appearance of often-interconnected ellipsoidal lesions on shoots and cankers (Demuner \& Ferreira, 1994). Leaf spots are circular, light brown to red in color and can lead to defoliation. Major damage has been observed in susceptible clones where dieback of mini-stumps is observed. During favorable environmental conditions, the lesions expand and can lead to stem girdling and plant death (Figure 1). Pink-cream spore masses are commonly observed on the lesions (Alfenas et al., 2009). The cause of the disease has been attributed to Colletotrichum gloeosporioides (Penz.) Penz. \& Sacc (Ferreira \& Milani, 2002; Alfenas et al., 2009; Mendes \& Urben, 2013). However, the identification to species was based only on morphology, whereas an accurate identification of a Colletotrichum species should combine both morphological and molecular approaches (Hyde et al., 2010; Cai et al., 2011; Weir et al., 2012; Cannon et al., 2012).

Recently, several cryptic species of $C$. gloeosporioides sensu lato have been proposed within the C. gloeosporioides complex based on the analysis of DNA sequence data (Phoulivong et al., 2010; Cannon et al., 2012; Weir et al., 2012). The Q-bank Fungi database provides data of strains that are regarded as type material or reference strains of Colletotrichum spp. (Raak \& Groenewald, 2013). The objective of this study was to determine the cause of a leaf spot disease leading to defoliation and death of eucalyptus mini-cuttings in nurseries based on DNA sequencing and morphological traits.

In 2012, plants of hybrid clones of Eucalyptus urophylla $\mathrm{x}$ E. grandis exhibiting leaf spots and stem girdling were collected from nurseries in the Brazilian states of Pará and Minas Gerais. Fungal structures were removed from symptomatic plants, mounted in drops of lactic acid on microscope slides and observed under a light microscope (FC Motic BA 210). The conidial sizes were determined based on 30 measurements.

Three isolates were obtained from single-spore suspensions and grown on potato-dextrose-agar (PDA) at $25^{\circ} \mathrm{C}$; the resulting cultures were then deposited at the Coleção de Culturas de Fungos Fitopatogênicos "Prof. Maria Menezes", Universidade Federal Rural de Pernambuco (UFRPE), Brazil (codes CMM 3559, CMM 3561 and 

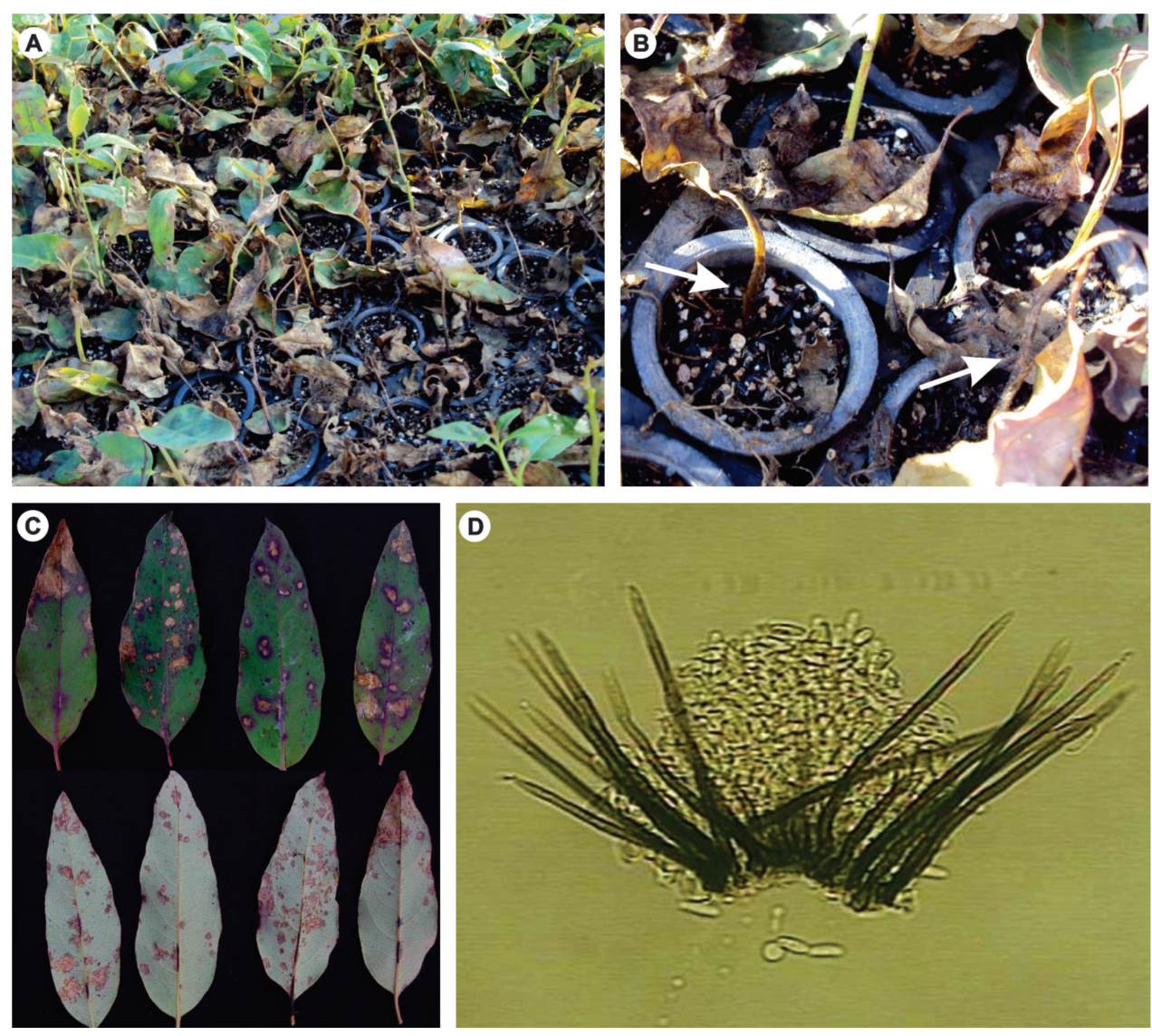

FIGURE 1 - Anthracnose in mini-cuttings of eucalyptus "urograndis" (Eucalyptus grandis x Eucalyptus urophylla) caused by Colletotrichum theobromicola. A. Minicuttings showing leaf spots and defoliation; B. stem girdling; C. spots on the abaxial and adaxial side of the leaf; $\mathbf{D}$. acervulus of C. theobromicola.
CMM 3565). Total DNA was extracted using the Wizard Genomic DNA Purification Kit (Promega) following the protocol described by Pinho et al. (2012).

Target regions of the internal transcribed spacer regions 1 and 2, including the 5.8S rRNA gene (ITS), $\beta$-tubulin ( $\beta \mathrm{t}$ ) and glyceraldehyde-3-phosphate dehydrogenase (GAPDH), were amplified using primers ITS1 and ITS4 for ITS (White et al., 1990); Bt2a and Bt2b for partial $\beta \mathrm{t}$ (Glass \& Donaldson, 1995) and GDF and GDR for partial GAPDH (Templeton et al., 1992).

PCR reactions included the following ingredients in each $25 \mu \mathrm{L}$ reaction: $12.5 \mu \mathrm{L}$ of Dream Taq TM PCR Master Mix 2X (MBI Fermentas); $1 \mu \mathrm{L}$ of $10 \mu \mathrm{M}$ of each forward and reverse primer, which were synthesized by Invitrogen; $1 \mu \mathrm{L}$ of dimethyl sulfoxide (DMSO, SigmaAldrich); $5 \mu \mathrm{L}$ of $100 \times(10 \mathrm{mg} / \mathrm{mL})$ bovine serum albumin (BSA, Sigma-Aldrich); $2 \mu \mathrm{L}$ of genomic DNA $(25 \mathrm{ng} / \mu \mathrm{L})$; and nuclease-free water to complete the total volume. PCR cycle parameters were the same as described by Weir et al. (2012). PCR products were purified and sequenced by Macrogen Inc., South Korea.

The nucleotide sequences were edited with BioEdit software (Hall, 2012). All sequences were manually checked, and nucleotides with ambiguous positions were clarified using the sequences from both primer directions. New sequences were deposited in GenBank (http://www. ncbi.nlm.nih.gov). Sequences for ITS, $\beta \mathrm{t}$ and GAPDH from the additional species were retrieved from GenBank (Table 1).

Consensus sequences of the ITS, $\beta \mathrm{t}$ and GAPDH regions were compared against the Q-bank Fungi database. In addition, DNA sequences were selected from Weir et al. (2012) to confirm the identity of Colletotrichum. The closest DNA sequence matches were aligned using MUSCLE (Edgar, 2004), built in MEGA v. 5 software (Tamura et al., 2011). The alignments were checked manually, and adjustments were made where needed. All the aligned regions within the dataset were included in the analysis. The resulting alignment and tree were deposited into TreeBASE (http://www.treebase.org; accession number: S14499).

Bayesian inference (BI) analysis employing a Markov Chain Monte Carlo method was performed with all sequences, first with each gene/locus separately and then with the concatenated sequences (ITS, $\beta$ t and GAPDH). The SYM+I model of evolution was used for ITS, the HKY $+\mathrm{G}$ model for $\beta t$ and the HKY $+\mathrm{I}$ model for GAPDH. The phylogenetic analysis of the concatenated alignment was performed using the CIPRES webportal (Miller et al., 2010) following the procedures described elsewhere (Pinho et al., 2012).

To confirm pathogenicity, a suspension of $10^{5}$ conidia/mL was sprayed on healthy plants of a hybrid "urograndis" clone (CPC 011) of Eucalyptus urophylla $\mathrm{x}$ E. 
grandis. Five 3-month old plants were inoculated with the conidial suspension, and five control plants were sprayed with autoclaved distilled water. The plants were incubated in a moist chamber for $24 \mathrm{~h}$ at $24^{\circ} \mathrm{C}$ and then moved onto a $25^{\circ} \mathrm{C}$ growth chamber where they were monitored daily until symptoms appearance.
Four days after inoculation, the plants showed irregular dark-brown leaf spots with dark brown coloration. The spots became necrotic, and leaves appeared dry. Fungal structures appeared in the center of the spot around one week later. The control plants showed no symptoms. Colletotrichum sp. was successfully re-isolated from the symptomatic plants.

TABLE 1 - GenBank accession numbers of the Colletotrichum/Glomerella DNA sequences used in the phylogenetic analysis.

\begin{tabular}{|c|c|c|c|c|}
\hline Species & Isolate & ITS $^{1}$ & GAPDH $^{2}$ & TUB2 $^{3}$ \\
\hline C. aenigma & ICMP 18608 & JX010244 & JX010044 & JX010389 \\
\hline C. aenigma & ICMP 18686 & JX010243 & JX009913 & JX010390 \\
\hline C. aeschynomenes & ICMP 17673 & JX010176 & JX009930 & JX010392 \\
\hline C. alatae & ICMP 17919 & JX010190 & JX009990 & JX010383 \\
\hline C. alatae & ICMP 18122 & JX010191 & JX010011 & JX010449 \\
\hline C. alienum & ICMP 12071 & JX010251 & JX010028 & JX010411 \\
\hline C. aotearoa & ICMP 18537 & JX010205 & JX010005 & JX010420 \\
\hline C. aotearoa & ICMP 18535 & JX010201 & JX009968 & JX010423 \\
\hline C. asianum & ICMP 18696 & JX010192 & JX009915 & JX010384 \\
\hline C. asianum & ICMP 18580 & FJ972612 & JX010053 & JX010406 \\
\hline C. boninense & ICMP 17904 & JX010292 & JX009905 & JQ005588 \\
\hline C. clidemiae & ICMP 18706 & JX010274 & JX009909 & JX010439 \\
\hline C. clidemiae & ICMP 18658 & JX010265 & JX009989 & JX010438 \\
\hline C. cordylinicola & ICMP 18579 & JX010226 & JX009975 & JX010440 \\
\hline C. fructicola & ICMP 18581 & JX010165 & JX010033 & JX010405 \\
\hline C. fructicola & ICMP17921 & JX010181 & JX009923 & JX010400 \\
\hline C. gloeosporioides & ICMP 17821 & JX010152 & JX010056 & JX010445 \\
\hline C. gloeosporioides & ICMP 19121 & JX010148 & JX010054 & - \\
\hline C. horii & ICMP 10492 & GQ329690 & GQ329681 & JX010450 \\
\hline C. horii & ICMP 17968 & JX010212 & GQ329682 & JX010378 \\
\hline C. kahawae & ICMP 17922 & JX010238 & JX010042 & JX010432 \\
\hline C. kahawae & ICMP 17816 & JX010231 & JX010012 & JX010444 \\
\hline C. musae & ICMP 19119 & JX010146 & JX010050 & HQ596280 \\
\hline C.musae & ICMP 17817 & JX010142 & JX010015 & JX010395 \\
\hline C. nupharicola & CMP 17938 & JX010189 & JX009936 & JX010397 \\
\hline C. nupharicola & ICMP 18187 & JX010187 & JX009972 & JX010398 \\
\hline C. psidii & ICMP 19120 & JX010219 & JX009967 & JX010443 \\
\hline C. queenslandicum & ICMP 17921 & JX010185 & JX010036 & JX010412 \\
\hline C. queenslandicum & ICMP 1778 & JX010276 & JX009934 & JX010414 \\
\hline C. salsolae & ICMP 19051 & JX010242 & JX009916 & JX010403 \\
\hline C. salsolae & ICMP 18693 & JX010241 & JX009917 & - \\
\hline C. siamense & ICMP 18578 & JX010171 & JX009924 & JX010404 \\
\hline C. siamense & ICMP 18642 & JX010278 & JX010019 & JX010410 \\
\hline C. theobromicola & ICMP 17957 & JX010289 & JX009962 & JX010380 \\
\hline C. theobromicola & ICMP 17927 & JX010286 & JX010024 & JX010373 \\
\hline C. theobromicola & ICMP 18649 & JX010294 & JX010006 & JX010447 \\
\hline C. theobromicola & CMM 3559 & KF768556 & KF768562 & KF768559 \\
\hline C. theobromicola & СМM 3561 & KF768555 & KF768561 & KF768558 \\
\hline C. theobromicola & СМM 3565 & KF768554 & KF768560 & KF768557 \\
\hline C. $t i$ & ICMP 5285 & JX010267 & JX009910 & JX010441 \\
\hline C. $t i$ & ICMP 4832 & JX010269 & JX009952 & JX010442 \\
\hline C. tropicale & ICMP 18653 & JX010264 & JX010007 & JX010407 \\
\hline C. tropicale & ICMP 18672 & JX010275 & JX010020 & JX010396 \\
\hline C. xanthorrhoeae & ICMP 17903 & JX010261 & JX009927 & JX010448 \\
\hline C. xanthorrhoeae & ICMP 17820 & JX010260 & JX010008 & - \\
\hline G. cingulata f. sp. camelliae & ICMP 10643 & JX010224 & JX009908 & JX010436 \\
\hline G. cingulata f. sp. camelliae & ICMP 18542 & JX010223 & JX009994 & JX010429 \\
\hline
\end{tabular}

${ }^{1}$ ITS: internal transcribed spacer regions; ${ }^{2} \mathrm{GAPDH}$ : glyceraldehyde-3-phosphate dehydrogenase; ${ }^{3} \mathrm{TUB} 2: \beta$-tubulin. The isolates used in this study are highlighted in bold. CMM stands for "Coleção de culturas de fungos fitopatogênicos Prof. Maria Menezes". 
The isolates grown on PDA medium produced colonies with white to gray mycelial coloration that after 2 to 3 days became black, with orange spore masses. Conidia were hyaline, straight, subcylindrical to clavate, $10-17 \times 4-6 \mu \mathrm{m}$ in size and often had broadly rounded ends. These isolates were morphologically typical of the C. gloeosporioides species complex (Cannon et al., 2008; Rojas et al., 2010; Weir et al., 2012).

As differences between Colletotrichum spp. are slight and the ranges of conidial size overlap, morphology alone cannot discriminate species in the $C$. gloesporioides complex (Phoulivong et al., 2010; Weir et al., 2012). Weir et al. (2012) evaluated seven protein coding genes and recommend two genes ( $\beta \mathrm{t}$ and GAPDH), in addition to ITS, for distinguishing members of the $C$. gloeosporioides species complex based on DNA sequence analysis. Searches on the Q-bank Fungi database using the ITS, $\beta$ t and GAPDH gene sequences for our isolates retrieved Colletotrichum theobromicola Delacr. with 100, 100 and 99\% identity, respectively. The resulting tree (Figure 2) supported this finding.

Colletotrichum theobromicola is one of 22 described species of the C. gloeosporioides species complex (Rojas et al., 2010; Weir et al., 2012). This fungus was first described in association with Theobroma cacao (Rojas et al., 2010),

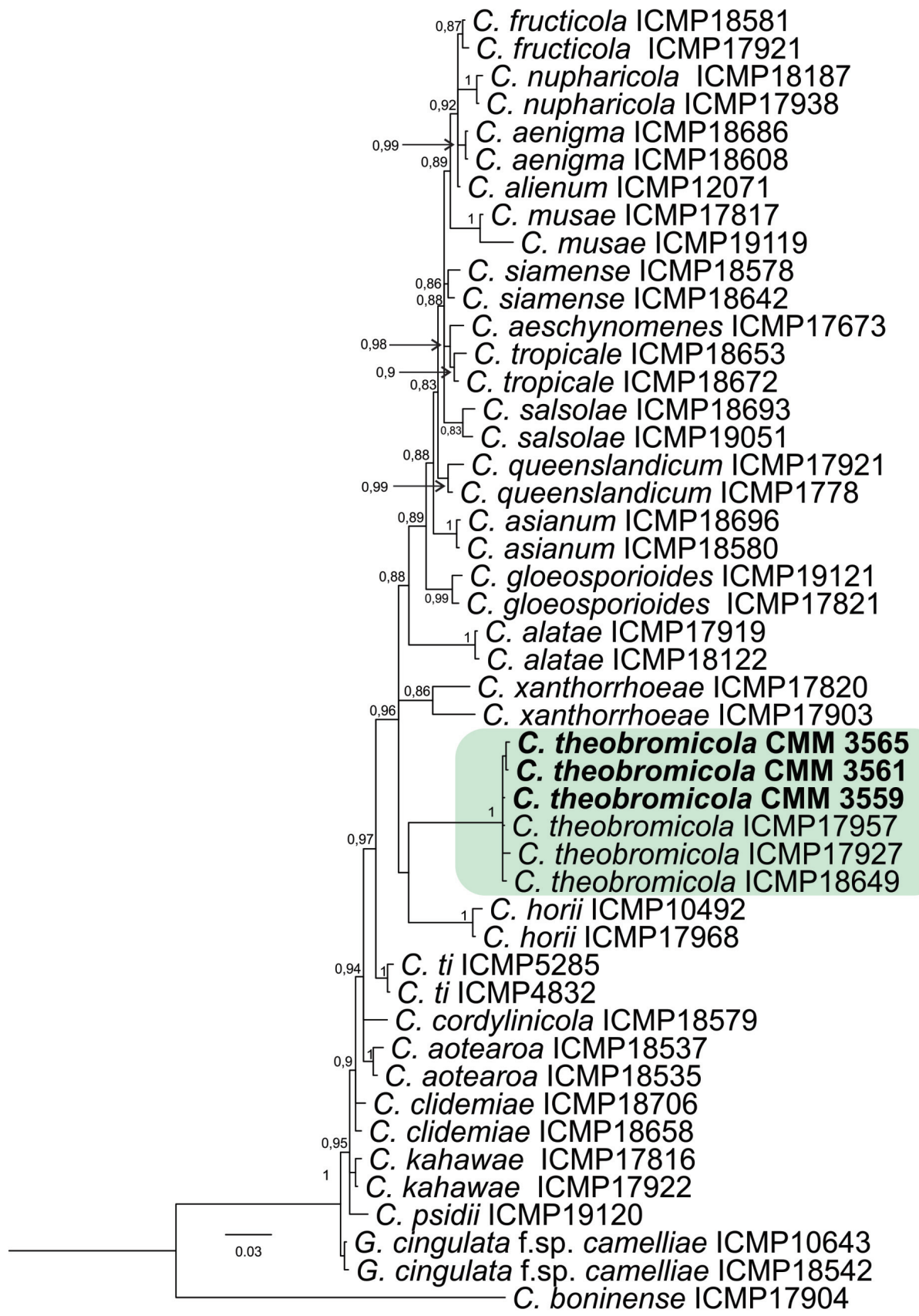

FIGURE 2 - Multi-locus phylogenetic tree inferred from Bayesian analysis using the ITS, $\beta$-tubulin and GAPDH regions. Bayesian posterior probability values $>0.7$ are indicated above the nodes. The isolates used in this study are highlighted in bold. The tree was rooted to Colletotrichum boninense. 
and has been reported in several other plants including Acca sellowiana, Annona diversifolia, Fragaria $\times$ ananassa, Fragaria vesca, Limonium sp., Olea europaea, Quercus sp., Stylosanthes guianensis and S. viscose; the pathogen is only known to occur in Australia, Israel, Mexico, New Zealand, Panama and the United States of America (Weir et al., 2012). This is the first report of C. theobromicola causing leaf spot, stem lesions and defoliation on eucalyptus and the first record of the species in Brazil. The disease poses a threat to nurseries of eucalyptus mini-cuttings where spray irrigation facilitates inoculum dissemination and the environment is favorable for disease outbreaks.

\section{ACKNOWLEDGEMENTS}

We thank the Cenibra S/A for providing the eucalyptus clone used in this study. This work was supported by Conselho Nacional de Desenvolvimento Científico e Tecnológico CNPq, Coordenação de Aperfeiçoamento de Pessoal de Nível Superior - CAPES, and Fundação de Amparo à Pesquisa do Estado de Minas Gerais - FAPEMIG.

\section{REFERENCES}

ABRAF (2013) Anuário estatístico ABRAF 2013, ano base 2012. Available at: http://www.abraflor.org.br/estatisticas/ABRAF13/ ABRAF13_BR.pdf Accessed on October 31, 2013.

Alfenas AC, Zauza EAV, Mafia RG, Assis TF (2009) Clonagem e Doenças do Eucalipto. $2^{\mathrm{a}}$ Ed. Viçosa, MG. Editora UFV.

Cai L, Udayanga D, Manamgoda DS, Maharachchikumbura SSN, McKenzie EHC, Guo LD, Liu XZ, Bahkali A, Hyde KD (2011) The need to carry out re-inventory of plant pathogenic fungi. Tropical Plant Pathology 36:205-213.

Cannon PF, Buddie AG, Bridge PD (2008) The typification of Colletotrichum gloeosporioides. Mycotaxon 104:189-204.

Cannon PF, Damm U, Johnston PR, Weir BS (2012) Colletotrichum current status and future directions. Studies in Mycology 73:181-213.

Edgar RC (2004) MUSCLE: multiple sequence alignment with high accuracy and high throughput. Nucleic Acids Research 32:1792-1797.

Ferreira FA, Demuner AMM (1994) Cancros e antracnose por Colletotrichum gloesporioides (Glomerella cingulata) em eucalipto. In: XXVII Congresso Brasileiro de Fitopatologia, Resumos...Itajaí, SC. Sociedade Brasileira de Fitopatologia. p.274.

Ferreira FA, Milani D (2002) Diagnose Visual e Controle das Doenças Abióticas e Bióticas do Eucalipto no Brasil. Mogi Guaçu, SP. International Paper.

Glass NL, Donaldson GC (1995) Development of primer sets designed for use with the PCR to amplify conserved genes from filamentous Ascomycetes. Applied and Environmental Microbiology 61:1323-1330.

Hall T (2012) BioEdit v7.0.9: Biological sequence alignment editor for Win95/98/2K/XP/7. Available at: http://www.mbio. ncsu.edu/bioedit/bioedit.html Acessed on 15 July 2012.

Hyde KD, Abd-Elsalam K, Cai L (2010) Morphology: still essential in a molecular world. Mycotaxon 114:439-451.

Mendes MAS, Urben AF (2012) Fungos relatados em plantas no Brasil, Laboratório de Quarentena Vegetal. Brasília, DF: Embrapa Recursos Genéticos e Biotecnologia. Available at: http://pragawall. cenargen.embrapa.br/aiqweb/michtml/fgbanco01.asp Acessed on 16 July 2013.

Miller MA, Pfeiffer W, Schwartz T (2010) Creating the CIPRES Science Gateway for inference of large phylogenetic trees. In: Proceedings of the Gateway Computing Environments Workshop (GCE). New Orleans LA, USA. pp. 1-8.

Phoulivong S, Cai L, Chen H, McKenzie EHC, Abdelsalam K, Chukeatirote E, Hyde KD (2010) Colletotrichum gloeosporioides is not a common pathogen on tropical fruits. Fungal Diversity 44:33-43.

Pinho DB, Firmino AL, Pereira OL, Ferreira Junior WG (2012) An efficient protocol for DNA extraction from Meliolales and the description of Meliola centellae sp. nov. Mycotaxon. 122:333345 .

Raak MV, Groenewald E (2013) Q-bank Fungi database: comprehensive databases on quarantine plant pests and diseases. Available at: http://www.q-bank.eu/Fungi/ Accessed on 16 July 2013.

Rojas EI, Rehner SA, Samuels GJ, Van Bael SA, Herre EA, Cannon P, Chen R, Pang J, Wang R, Zhang Y, Peng YQ, Sha T (2010) Colletotrichum gloeosporioides s.l. associated with Theobroma cacao and other plants in Panama: multilocus phylogenies distinguish host-associated pathogens from asymptomatic endophytes. Mycologia 102:1318-1338.

Tamura K, Peterson D, Peterson N, Stecher G, Nei M, Kumar S (2011) MEGA5: Molecular evolutionary genetics analysis using Maximum Likelihood, Evolutionary Distance, and Maximum Parsimony Methods. Molecular Biology Evolution 28:27312739.

Templeton MD, Rikkerink EHA, Solon SL, Crowhurst RN (1992) Cloning and molecular characterization of the glyceraldehyde-3phosphate dehydrogenase-encoding gene and cDNA from the plant pathogenic fungus Glomerella cingulata. Gene 122:225-230.

Weir B, Johnston PR, Damm U (2012) The Colletotrichum gloeosporioides species complex. Studies in Mycology 73:115-180.

White TJ, Bruns T, Lee S, Taylor J (1990) Amplification and direct sequencing of fungal ribosomal RNA genes for phylogenetics. In: Innis MA, Gelfand DH, Sninsky JJ, White TJ (Eds.) PCR Protocols: A Guide to Methods and Applications. San Diego, CA, USA. Academic Press. pp. 315-322. 